\title{
Person and Power. A Way to Explore Religious Conversions Among the Tzotzil Mayas from Chiapas, Mexico
}

\author{
David Montoya* \\ Faculty of Philosophy and Letters, National Autonomous University of Mexico, Mexico
}

Submission: September 15, 2019; Published: September 24, 2019

*Corresponding author: David Montoya, Postgraduate in Mesoamerican Studies, Faculty of Philosophy and Letters, National Autonomous University of Mexico, Mexico

Abstract

Addressing cosmological aspect, in one hand, and political-social aspects, on the other, is nearly a constant in anthropological studies. That is, there is a clear trend to reduce to our own terms the political-social phenomena, and on the other extreme, to highlight the complexities of the ritual lives of the indigenous peoples. With some exceptions, the disassembling between those processes is the common denominator of the studies about the Mesoamerican region. In an effort to contribute to such exceptions, in this opinion paper I offer arguments that suggest that religious conversion, power, and the notion of person, fully overlap, at least among the Tzotzil Mayas of San Juan Chamula, in Highland Chiapas, Mexico.

Keywords: Notion of Person; Religious Conversion; Power; Tzotzil Mayas; Chamula

\section{Introduction}

The openness to accept new churches or religious groups by Amerindian groups has given raise to an extensive amount of research. It's not the openness displayed by these populations which draws the attention of the academia, but the devoted adherence interest that is easily forgotten later. Some call this trait: "The inconstancy of the indian souls" [1] and others: "indigenous infidelity" [2]. Apart from these and other exceptions [3], most of the studies reduce the complexities of this phenomenon by extrapolating the reality conditions typical of naturalistic ontology $[4,5]$. Notions such as the person [6], for example, are usually not included in those approaches. On an opposite pole, the notion of person, at least in the region under study, has guided numerous studies to mainly address the health-sickness-treatment process [7]. Others, in an attempt to know the continuities and discontinuities of the existing, show that the Tzotzil person does not exclude the animal (the chon) from the human, but that together form a unit, although they differentiate in the ways they relate: the first through depredation; the second, through alliances. That is, the chon operates similarly to the principles of the trophic chain: the upper level is the residence of the big predators, who, potentially, prey upon those in the lower level [8]; while the human side makes alliances with groups of power to counteract the former. Of course, there in an interdependence relationship between both sides: What happens to the chon will have repercussions on its human counterpart. Moreover, the social status of the latter depends on the trophic level of the former.
This complexity in the integration of person makes it extremely vulnerable: Perils of the soul, some would say [9]. A transgression may lead to the release - opening the farmyard - of the "animal" counterparties and cause exposure to multiple dangers [10].

\section{The Vulnerable Person}

Generally, all people are considered a potential enemy; even the same blood relatives live in a state of alert. The tenel, for example, is a way to harm the chon of a young blood relative. Anyone afflicted with tenel is a "discarded" person, forgotten, even by higher ranking familiars. Mistrust and vulnerability are common conditions to the point that: "Most deaths, to the Chamula Tzotzils, are deemed homicides"[11]. Conflict prevention and mediation is reached by a series of negotiations between humans, and between humans and God and the saints mainly; only in cases of remediation or treatment, the intervention of a ritual specialists becomes necessary. If danger is a constant, then establishing alliances with people known to be powerful, whose animal counterparties thus are at the top of the trophic chain, becomes necessary. The priority is not necessarily gaining a privileged position to see others as potential prey or inferior beings; the main concern is to reduce the number of threats. That way, the alliance allows to relate with the higher trophic level beings as equals. That is, the main concern is to avoid maladies, prevent danger and not necessarily pretend to subjugate those at the bottom of the trophic chain, although in some cases this 
apparent "advantage" is leveraged. Alliances, in short, is a quite effective form to prevent a malady, however, efforts are never enough: The risk to switch between ally and enemy is always latent.

\section{Conversions or Mechanisms to Form Alliances and Gain Power?}

Constant conversions to new religious organizations "depend on what each church offers to have a healthy and prosperous life and prevent evil and disease"[2]. For the Chamula case, I would include the summoning power and social recognition of the minister and the church itself. It's not a coincidence that during nearly 30 years - since 1965, approximately - Chamula ranked near the top of the region in regard to prosecution and expulsions of the Evangelical population in their municipality, and that religious intolerance only waned after the Evangelical faith gained prominence in Chiapas and an important Evangelical leader was voted governor of the state from 2000-2006, to the point that, nowadays, the municipality is full of evangelic temples, and stewardship positions can be covered by Evangelical Chamulas.

The conversion of Manuel San Juan, who is said to be responsible of the expulsion over more than one thousand Evangelical families from Chamula, is one of the more notable cases. His actions in favor of tradition made him infamous among both Traditionalists and Evangelicals as someone dedicated to abuse and expel the converts [12]. However, the life of Manuel had a radical turn: currently he is an important Evangelical leader with a temple near his house. It is possible that, as it happens with other groups such as the Tzeltal or peoples of other farther regions, such as the Wari', that conversion to Christianity, or any other religion, may be moderated by the opportunity of gaining new understanding: learning new insights and become something new [3]. It is clear that deeper study is required to address such a complex subject, however, it is possible to observe, in general, that religious conversion has to do with the possibility of becoming part of a powerful network and to try a different way of life in order to mitigate diverse dangers.

\section{Conclusion}

If potentially anyone can be preyed upon, the constitution of groups of power by way of alliances is a viable way to prevent "evil" and "disease". To associate with someone with recognition and power is, by extension, to become powerful and recognized and less vulnerable. This is how godfatherhood operates: Having more ritual relatives (allies) gains more recognition, and thus, less vulnerability. It's not a coincidence that the word tsots (hair, wool), from which the gentilic Tzotzil originates, is related to tsatsal, power [13]. Tsatsal kuxlejal, for example, is the expression used to refer the way of life of an human with plenty of prestige and power, someone who knows to relate with humans and supernatural beings. In many prayers, God, and the saints as well, are referred to as tsatsal vinik, tsatsal kaxlan: powerful man or powerful ladino, respectively. The relationship between tsatsal, tsots, alliance and power, is evident through garments, which distinguishes them from other Tzotzil people: traditional clothes, for men and women, are manufactured from Chiapas lamb wool, which is a long-haired species. They are manufactured in such a way that the more wool texture is exposed, the longer and more abundant the hair locks are, and thus more valued in the social and economic sense. To dress "of sheep and like sheep" is not a fancy. These are the chon of Saint John the Baptist, considered one of the most powerful saints in the Tzotzil cosmos. Therefore, using those garments suggests a relationship with the saint; it's even comparable to stating: "I am a son of Saint John", which in the past was the reply when a ladino asked someone about their place of origin, as many Chamula assert. It is an ethnical model that denotes power by showing adherence to Saint John, considered one of the most powerful saints in the region. In general, the success of a human consists of becoming part of a powerful network, which manifests as social recognition, and thus mitigates vulnerability against predators. That is, gaining a higher social status that, in other words, equates to adopting a chon from a higher trophic level. It is said that a full and powerful human can possess up to thirteen chon [10].

\section{References}

1. Viveiros CE (2011) The inconstancy of the indian soul: The encounter of catholics in $16^{\text {th }}$ Century Brazil, The University of Chicago Press, UK.

2. Pitarch $P$ (2013) Indigenous infidelities. In: Pitarch P (Ed.), The Hidden Face of the $1^{\text {st }}\left(\mathrm{Ed}^{\mathrm{n}}\right)$ Arts of Mexico, Conaculta, Mexico, pp 165-180.

3. Vilaça A (2016) Praying and preying. Christianity in indigenous Amazonia. $1^{\text {st }}\left(\mathrm{Ed}^{\mathrm{n}}\right)$ University of California Press, Oakland, California, USA.

4. Rivera Farfán C (2013) Censored religious beliefs and practices. Expulsion of indigenous evangelicals due to change of religious affiliation. In: Torrens 0 (Ed.), Forced displacement in Mexico. An approach for reflection and analysis $1^{\text {st }}\left(\operatorname{Ed}^{\mathrm{n}}\right)$, CIESAS, Colegio de Sonora, Mexico, pp 75-111.

5. Uribe CJ, Martínez VG (2012) Religious change, indigenous expulsions and conformation of evangelical organizations in Los Altos de Chiapas. Politics and culture 38: 141-161.

6. Hallowell AI (1981) Ojibwa ontology, behavior and world view. In: Diamond S (Ed.), Culture in History: Essays in honor of Paul Radin, Octagon Books, New York, USA, pp 19-52.

7. Page JT (2007) Presentation to the Dossier on the notion of person. Peoples and Borders 4: 1-4.

8. Del Rosario F (2016) Animal otherness Other food: predation and animal components of man, Mexico.

9. Guiteras C (1988) Los peligros del alma. Visión del mundo de un tzotzil $1^{\text {st }}\left(E^{\mathrm{n}}\right)$ Editorial de Ciencias Sociales de La Habana, La Habana, Cuba.

10. Gossen GH (1975) Animal Souls and Human Destiny in Chamula. Man 10(3): 448-461.

11. Favre H (1964) Notes on homicide between the chamula. Studies of Mayan Culture 4: 305-322.

12. Henríquez E (2008) Manuel San Juan: from an expeller of evangelicals to a promoter of the faith. The online conference.

13. Laughlin RM (2009) Mol cholobil k'op ta sotz'leb $1^{\text {st }}\left(\mathrm{Ed}^{\mathrm{n}}\right)$, Cultura de los Indios Mayas AC, Ciudad de México, Mexico. 


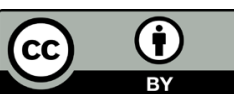

This work is licensed under Creative Commons Attribution 4.0 License DOI: 10.19080/GJAA.2019.10.555795
Your next submission with Juniper Publishers will reach you the below assets

- Quality Editorial service

- Swift Peer Review

- Reprints availability

- E-prints Service

- Manuscript Podcast for convenient understanding

- Global attainment for your research

- Manuscript accessibility in different formats ( Pdf, E-pub, Full Text, Audio)

- Unceasing customer service

Track the below URL for one-step submission https://juniperpublishers.com/online-submission.php 